\begin{tabular}{|c|c|c|}
\hline $\begin{array}{l}\text { JURNAL } \\
\text { INOVASI } \\
\text { TEKNOLOGI } \\
\text { PENDIDIKAN }\end{array}$ & $\begin{array}{l}\text { Jurnal Inovasi Teknologi Pendidikan } \\
\text { Volume 5, No 1, April } 2018 \text { (48-60) } \\
\text { Online: http://journal.unv.ac.id/index.php/iitp }\end{array}$ & $\begin{array}{l}\text { Ikatan Profesi Teknologi } \\
\text { Pendidikan Indonesia }\end{array}$ \\
\hline
\end{tabular}

\title{
PENGEMBANGAN VIDEO DIGITAL PENGALENGAN BUAH DAN SAYUR UNTUK MATA KULIAH TEKNOLOGI PENGOLAHAN HASIL PERTANIAN
}

\author{
Roesnia Dwi Pratitasari 1*, Abdul Gafur 2 \\ ${ }^{1}$ Akademi Komunitas Negeri Temanggung \\ 2Universitas Negeri Yogyakarta UNY \\ 1Jl. Kadar Maron Kotak Pos 104 Sidorejo, Temanggung, Jawa Tengah, Indonesia \\ 2J1. Colombo No. 1, Depok, Sleman 55281, Yogyakarta, Indonesia \\ * Corresponding Author. Email: nianiol1087@gmail.com
}

\begin{abstract}
Abstrak
Penelitian ini bertujuan: (1) menghasilkan video digital pengalengan buah dan sayur untuk mata kuliah teknologi pengolahan hasil pertanian, (2) mengetahui kelayakan video digital pengalengan buah dan sayur pada mata kuliah teknologi pengolahan hasil pertanian di Akademi Komunitas Negeri Temanggung, dan (3) mengetahui keefektifan video digital pengalengan buah dan sayur pada mata kuliah teknologi pengolahan hasil pertanian di Akademi Komunitas Negeri Temanggung. Penelitian pengembangan ini mengacu pada langkah yang dikembangkan oleh Borg and Gall. Desain pengembangan dikelompokkan menjadi tiga prosedur pengembangan, yang meliputi: (a) analisis kebutuhan, (b) pengembangan produk, dan (c) validasi dan revisi. Teknik pengumpulan data menggunakan kuesioner dan tes. Data yang diperoleh dianalisis secara deskriptif kuantitatif. Efektifitas produk dianalisis menggunakan rumus $\mathrm{N}$-gain (hasil belajar yang dinormalisasi). Hasil penelitian menunjukkan (1) produk yang dihasilkan adalah video digital pengalengan buah dan sayur, (2) produk yang dikembangkan layak digunakan sebagai salah satu sumber belajar dilihat dari aspek media dan aspek materi, dan (3) efektifitas pengembangan produk termasuk kategori tinggi.
\end{abstract}

Kata kunci: video digital, pengalengan buah dan sayur

\section{DEVELOPING DIGITAL VIDEO OF CANNING FRUITS AND VEGETABLES FOR AGRICULTURAL PRODUCTS PROCESSING TECHNOLOGY COURSE}

\begin{abstract}
This research aims to: (1) produce digital video canning of fruits and vegetables for the course of technology processing of agricultural products, (2) determine the feasibility of digital video of canning fruits and vegetables in the subject of technological processing of agricultural products at the Academy of Community Affairs Temanggung, and (3) determine the effectiveness of digital video of canning fruits and vegetables in the subject of agricultural processing technology in Temanggung State Community college. The study is a research and development $(R \mathcal{E} D)$ adapted from Borg and Gall model that consist of analysis of needs, product development, and the validation and revision. The data were analyzed by descriptive qualitative. The effectiveness of the product was analyzed using the formula N-gain (normalized learning outcomes). The results of the research show that: (1) the resulted product is a digital video of canning fruits and vegetables, (2) the developed product is suitable to use as a learning resource of learning from the aspect of media and material aspects, and (3) the effectiveness of developed product is high.
\end{abstract}

Keywords: digital video, fruit and vegetable canning

Permalink/DOI: http://dx.doi.org/10.21831/jitp.v5i1.14526 


\section{Pendahuluan}

Pendidikan memiliki peranan yang penting dalam kehidupan. Pendidikan merupakan suatu kekuatan yang dinamis dalam kehidupan setiap individu yang mempengaruhi fisik, daya jiwa (akal, rasa dan kehendak), sosial dan moralnya. Menurut Kneller (1967, p. 63), pendidikan merupakan suatu proses, yaitu pendidikan merujuk pada suatu tindakan atau pengalaman yang mempunyai pengaruh terhadap perkembangan individu ( jiwa, watak dan kemampuan fisik), sedangkan dalam arti teknis (hasil) pendidikan dipandang sebagai proses masyarakat melalui lembaga-lembaga pendidikan formal dengan sengaja mentransformasikan warisan budayanya yaitu pengetahuan dan keterampilanketerampilan.

Meninjau pengertian pendidikan yang telah dikemukakan, maka dalam pendidikan akan terjadi pembelajaran. Pembelajaran yang dimaksud yaitu sebuah pembelajaran yang mampu membangun komunikasi yang berupa penyampaian pesan dari pedidik kepada peserta didik. Penyampaian pesan dapat secara langsung maupun melalui saluran yang berupa media. Sadiman (2008, p. 11) berpendapat bahwa proses belajar megajar merupakan suatu proses komunikasi, yaitu proses penyampaian pesan melalui saluran media tertentu ke penerima pesan.

Pendidikan Akademi Komunitas bertujuan untuk membekali kemampuan berupa keterampilan sesuai dengan potensi yang ada di lingkungan mahasiswa, sehingga keterampilan yang diperoleh dapat segera diaplikasikan secara langsung. Sesuai Peraturan Pemerintah Republik Indonesia pasal 1 ayat 12 Tahun 2014, menyatakan bahwa Akademi Komunitas adalah Perdosenan Tinggi yang menyelenggarakan pendidikan vokasi setingkat diploma satu dan/ atau diploma dua dalam satu atau beberapa cabang ilmu pengetahuan dan atau teknologi tertentu yang berbasis keunggulan lokal atau untuk memenuhi kebutuhan khusus (Presiden Republik Indonesia, 2014).
Menurut Ulumudin (2015, p. 10) Akademi Komunitas merupakan perguruan tinggi yang tepat untuk warga masyarakat yang kurang mampu, tetapi mempunyai motivasi belajar tinggi dan ingin cepat bekerja. Akademi Komunitas lokasinya berada di Kabupaten/kota tempat mahasiswa bertempat tinggal, sehingga biaya pribadi dapat berkurang. Strategi untuk mendekatkan lokasi Akademi Komunitas dengan mahasiswa ditujukan agar mahasiswa sekolah menengah yang berada di daerah pinggiran dapat melanjutkan pendidikan di Perguruan Tinggi tanpa mengeluarkan biaya yang banyak.

Akademi Komunitas Negeri Temanggung berlokasi di kabupaten Temanggung. Sebagai salah satu Pendidikan di Luar Domisili dari Politeknik Negeri Jember, Akademi Komunitas Negeri Temanggung berlokasi di SMK Negeri 1 Temanggung. Hal ini dikarenakan status dari Akademi Komunitas Negeri Temanggung yang belum menjadi satuan pendidikan yang mandiri. Pendidikan tinggi ini tidak membatasi usia dari mahasiswa yang berminat untuk belajar di dalamnya. Oleh karena itu Akademi Komunitas Negeri Temanggung mempunyai mahasiswa dari berbagai usia dan latar belakang pendidikan.

Berdasarkan latar belakang usia mahasiswa yang bervariasi dan mayoritas adalah orang dewasa. Dengan pembelajaran orang dewasa saat ini, perlu memperhatikan beberapa prinsip. Prinsip tersebut antara lain orang dewasa memiliki konsep diri, orang dewasa memiliki akumulasi pengalaman, orang dewasa mempunyai kesiapan belajar, orang dewasa segera ingin memanfaatkan hasil belajarnya, orang dewasa mempunyai kemampuan belajar, orang dewasa dapat belajar efektif apabila melibatkan mental dan fisik (Sudjana, 2007, p. 3).

Sebagai aktualisasi sifat akademi komunitas, Akademi Komunitas Negeri Temanggung mengajarkan beberapa disiplin Ilmu yang diajarkan dalam satu jenjang pendidikan program studi salah satunya Jurusan Teknologi Industri Pangan. Jurusan ini memiliki cakupan mata kuliah yang 
sangat luas dari berbagai disiplin ilmu diantaranya Mata Kuliah Teknologi Pengolahan Hasil Pertanian. Mata kuliah ini merupakan salah satu materi dasar yang harus dikuasai dengan baik oleh mahasiswa jurusan Teknologi Industri Pangan.

Mata kuliah Teknologi Pengolahan Hasil Pertanian memiliki cakupan materi yang sangat banyak berupa peristiwa, fakta, konsep, generalisasi dan keterampilan mengolah hasil pertanian yang harus dikuasai mahasiswa, salah satunya materi pengolahan hasil pertanian. Banyaknya cakupan materi dalam mata kuliah ini menuntut motivasi belajar dan pemahaman konsep yang baik dimiliki oleh mahasiswa dalam menguasai keterampilan mengolah hasil pertanian selama mengikuti perkuliahan mata kuliah ini.

Sebagai perwujudan pelaksanaan pembelajaran Mata Kuliah Teknologi Pengolahan Hasil Pertanian, beberapa strategi telah dilakukan oleh dosen untuk mengatasi permasalahan tersebut. Strategi pertama yaitu dengan memadatkan waktu perkuliahan teori dan menambah waktu perkuliahan praktik, namun strategi tersebut menimbulkan masalah baru karena motivasi dan pemahaman konsep belum ditunjukkan oleh mahasiswa. Strategi kedua yaitu dengan memberikan kuliah teori tambahan diluar jam pelajaran namun strategi ini belum mampu mengembangkan motivasi dan pemahaman konsepnyapun juga masih tergolong rendah.

Salah satu usaha untuk mengatasi permasalahan motivasi belajar dan pemahaman konsep mahasiswa dalam pembelajaran Mata Kuliah Pengolahan Hasil Pertanian yaitu dengan menitikberatkan pada strategi penyampaian pembelajaran dan strategi pengelolaan pembelajaran. Strategi penyampaian terkait dengan dikembangkannya media pembelajaran berupa video digital teknologi pengolahan hasil pertanian khususnya pengolahan menggunakan suhu tinggi. Pemilihan video digital dikarenakan video mampu menampilkan keseluruhan proses pengalengan secara utuh, video digital dapat digunakan tanpa bergan- tung dengan bahan ajar lainnya, materi pengalengan disajikan secara multimedia yang memuat unsur teks;animasi;suara, tampilan video digital ini menggunakan resolusi yang tinggi (Riyana, 2007, pp. 811). Strategi pengelolaan terkait dengan penjadwalan, pembuatan catatan kemajuan belajar yang mencakup motivasi belajar dan pemahaman konsep serta kontrol belajar yang berupa kebebasan mahasiswa dalam melakukan tindakan belajar selama menggunakan media video digital teknologi pengolahan hasil pertanian.

Media video memiliki kelebihan antara lain: (1) dengan menggunakan video baik disertai suara maupun tidak, kita dapat menunjukkan kembali gerakan tertentu; (2) dengan menggunakan efek tertentu dapat diperkokoh, baik proses belajar maupun nilai hiburan dari penyajian itu; (3) dengan video, informasi dapat disajikan secara serentak pada waktu yang sama di lokasi (kelas) yang berbeda dan dengan jumlah penonton atau peserta yang tak terbatas dengan jalan menempatkan monitor di setiap kelas; (4) dengan video siswa dapat belajar secara mandiri (Anderson, 1987, p. 105).

Pengembangan video digital merupakan salah satu solusi alternatif pemanfaatan sumber belajar yang dapat digunakan oleh mahasiswa sebagai media pembelajaran. Berdasarkan uraian dan berbagai permasalahan di atas, maka hal tersebut menjadi alasan bagi peneliti melakukan penelitian dalam hal pengem-bangan video digital dengan rumusan masalah yaitu; (1) bagaimana mengembangkan video digital pengalengan buah dan sayur pada mata kuliah teknik pengolahan hasil pertanian, (2) bagaimana kelayakan video digital pengalengan buah dan sayur pada mata kuliah teknologi pengolahan hasil pertanian, (3) bagaimana keefektifan video digital pengalengan buah dan sayur pada mata kuliah teknologi pengolahan hasil pertanian. Tujuan dari penelitian ini adalah (1) mengembangkan video digital pengalengan buah dan sayur pada mata kuliah teknologi pengolahan hasil pertanian di Akademi Komunitas Negeri Temanggung, (2) menge- 
tahui kelayakan video digital pengalengan buah dan sayur pada mata kuliah teknologi pengolahan hasil pertanian di Akademi Komunitas Negeri Temanggung, (3) mengetahui kelayakan video digital pengalengan buah dan sayur pada mata kuliah teknologi pengolahan hasil pertanian di Akademi Komunitas Negeri Temanggung.

Menurut Salim \& Salim (1996, p. 2230) dalam The Contemporary English-Indonesian Dictionary Video diartikan sebagai sesuatu yang berkenaan dengan penerimaan dan pemancaran gambar. Pendapat lain tentang video disampaikan oleh (Smaldino, Lowther, \& Russel (2011, p. 374), video adalah "the storage of visuals and their display on television-type screen" (penyimpanan/ perekaman gambar dan penanyangannya pada layar televisi). Arsyad (2011, p. 49) berpendapat bahwa video merupakan gambargambar dalam frame, dimana frame demi frame diproyeksikan melalui lensa proyektor secara mekanis sehingga pada layar terlihat gambar hidup.

Menurut (Riyana, 2007, p. 4) bahwa video digital adalah media yang menyajikan audio dan visual yang berisi pesan-pesan pembelajaran baik yang berisi konsep, prinsip, prosedur, teori aplikasi pengetahuan untuk membantu pemahaman terhadap suatu materi pembelajaran. Video merupakan bahan pembelajaran tampak dengar (audio visual) yang dapat digunakan untuk menyampaikan pesan/materi pelajaran. Dikatakan tampak dengar kerena unsur dengar (audio) dan unsur visual/video (tampak) dapat disajikan serentak.

Menurut Daryanto (2012, p. 86) menjelaskan bahwa video digital merupakan bahan ajar non-cetak yang kaya informasi dan tuntas karena dapat sampai kehadapan siswa secara langsung. Dengan demikian video digital diharapkan dapat menumbuhkan motivasi mahasiswa, merangsang mahasiswa mengingat materi kuliah yang telah dipelajari dari video digital yang dibuat.

Video digital dapat dimanfaatkan untuk semua topik, dan seluruh ranah/aspek pembelajaran (Smaldino, Lowther,
Russel, 2011, p. 404). Aspek pembelajaran seperti seperti: ranah kognitif, ranah afektif, ranah kemampuan motorik, ranah kemampuan interpersonal, kunjungan lapangan virtual, dokumenter, dramatisasi.

Karakteristik media video pembelajaran lainnya menurut (Riyana, 2007, p. 7) adalah: (1) video mampu membesarkan objek yang kecil, terlalu kecil bahkan yang tidak dapat dilihat secara kasat mata atau dengan mata telanjang, (2) dengan teknik editting objek yang dihasilkan dari pengambilan gambar oleh kamera dapat diperbanyak (cloning), (3) video mampu memanipulasi tampilan gambar, sesekali objek perlu diberikan manipulasi tertentu sesuai dengan tuntutan pesan yang ingin disampaikan sebagai contoh objek-objek yang terjadi pada masa lampau dapat dimanipulasi dengan masa sekarang, (4) video mampu membuat objek menjadi Still Picture artinya gambar atau objek yang ditampilkan dapat disimpan dalam durasi tertentu dalam keadaan diam; (5) daya tarik yang luar biasa dari video adalah mampu mempertahankan perhatian siswa/audience melihat video dengan baik, dibandingkan dengan mendengarkan saja (hanya mampu bertahan \pm 25 30 menit), (6) video mampu menampilkan objek gambar dan informasi yang paling baru, hangat dan aktual (immediacy) atau kekinian.

Karakteristik media video pembelajaran menurut (Arsyad, 2011, p.37-52.) adalah: (1) dapat disimpan dan digunakan berulang kali; (2) harus memiliki teknik khusus, untuk pengaturan urutan baik dalam hal penyajian maupun penyimpanan; (3) pengoperasiannya relatif mudah; (4) dapat menyajikan peristiwa masa lalu atau peristiwa ditempat lain.

Berdasarkan karakteristik media video pembelajaran diatas, disimpulkan karakteristik media video pembelajaran adalah: (1) dapat menyajikan peristiwa atau proses pengerjaan di tempat lain; (2) dapat digunakan secara berulang-ulang; (3) ditayangkan melalui televisi atau media player; (4) mampu mempertahankan perhatian siswa; (5) dapat digunakan secara klasikal atau 
individual; (6) pesan yang panjang dapat dibuat secara singkat; dan (7) menampilkan objek gambar dan informasi yang paling baru.

Di dalam penggunaannya di kelas video digital ini dapat ditayangkan dengan menggunakan laptop yang mempunyai perangkat pemutar video. Pengoperasiannya cukup mudah, sehingga para mahasiswa tidak mengalami kesulitan dalam menggunakannya. Video digital ini bukan merupakan satu-satunya sumber belajar namun diharapkan dapat membantu memecahkan permasalahan belajar.

\section{Metode Penelitian}

Penelitian ini merupakan penelitian pengembangan $(R \mathcal{E} D)$ yang bertujuan untuk menghasilkan sumber belajar berupa video digital. Fokus materi yang dikembangkan dalam video digital ini adalah pengalengan buah dan sayur, yang merupakan aplikasi dari teknik pengolahan hasil pertanian dengan suhu tinggi (Termal Process).

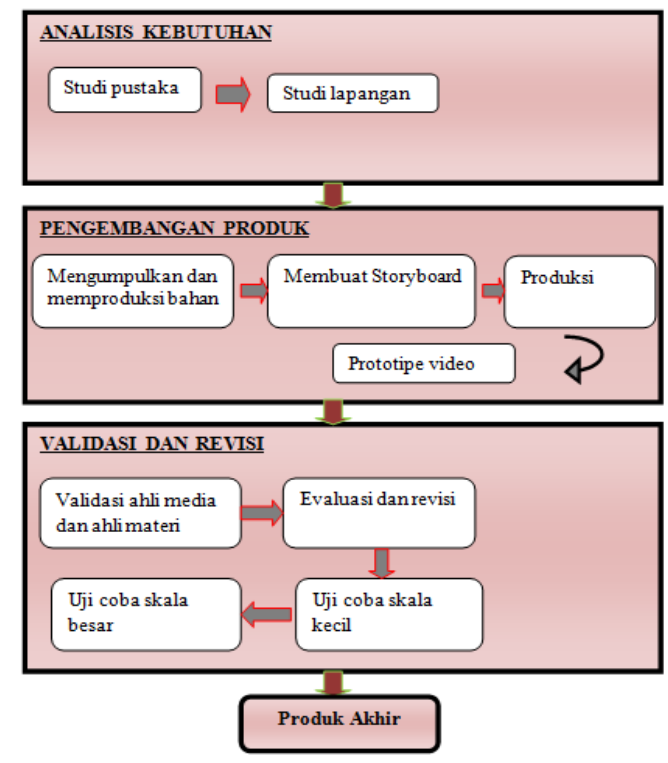

Gambar 1. Model Pengembangan Video Digital Pengalengan Buah dan Sayur

Model yang digunakan dalam penelitian ini adalah model pengembangan yang diadaptasi dari Borg \& Gall (1983, p. 775) yang terdiri dari analisis kebutuhan, pengembangan produk, serta validasi dan re- visi. Prosedur pengembangan video digital pengalengan buah dan sayur disajikan pada Gambar 1.

Tahap analisis kebutuhan dilakukan untuk mengumpulkan informasi pendukung. Tahap ini dilakukan melalui dua tahapan yaitu studi pustaka bertujuan mempelajari informasi tentang mata kuliah Teknologi pengolahan hasil pertanian di Akademi Komunitas Negeri Temanggung. Studi lapangan dilakukan untuk melihat secara langsung tentang keadaan lembaga pendidikan, potensi yang dimiliki, proses pembelajaran, dan dokumen hasil belajar mahasiswa.

Tahap pengembangan produk dilakukan denga mengumpulkan semua bahan pendukung. Dalam mengembangkan video digital ini juga disusun sebuah desain pembelajaran. Desain pembelajaran merupakan komponen yang penting dalam sebuah pembelajaran. Pembelajaran dapat berjalan dengan efektif dan efisien apabila disusun berdasarkan konsep pembelajaran dan sistem pembelajaran pada kurikulum yang dianut di Akademi Komunitas Negeri Temanggung. Pada penelitian pengembangan ini, desain pembelajaran disusun menggunakan model Dick, Carey, \& Carey (2001, pp. 2-3). Model desain pembelajaran yang digunakan dalam penelitian ini yaitu dalam bentuk system aproach model for designing instruction yang terdiri dari: (1) menetapkan tujuan instruksional umum dan tujuan instruksional khusus; (2) merumuskan indikator; (3) identifkasi karakteristik awal mahasiswa; (4) memilih materi kuliah; dan (5) menyusun strategi pembelajaran.

Setelah menyusun desain pembelajaran, produk mulai dikembangkan. Tahap pengembangan media dilakukan melalui langkah-langkah: (1) mengumpulkan ide, penulisan skrip dan membuat storyboard; (2) melakukan shooting dan capturing serta proses rekam suara dengan menggunakan kamera atau handycam; (3) hasil shooting dan capturing kemudian masuk ke dalam tahap editing dengan menggunakan adobe premiere; (4) hasil editing kemudian memasuki tahap compositing dan tahap pemberian visual 
effect; (5) prototype video digital pengalengan buah dan sayur.

Tahap validasi dilakukan oleh ahli media dan ahli materi bertujuan untuk mengevaluasi media pembelajaran apakah sudah sesuai dengan kriteria video pembelajaran yang mencakup semua sajian video pembelajaran sehingga layak digunakan sebagai media pembelajaran oleh peserta didik. Validasi media dan materi dilakukan oleh masing-masing 2 (dua) orang ahli. Tahap uji coba dilakukan dengan dua tahap yaitu uji coba skala kecil dan uji coba lapangan. Uji coba skala kecil dimaksudkan untuk mengetahui kelayakan dari video digital pengalengan buah dan sayur dilihat dari pengguna video. Uji coba lapangan digunakan untuk mengetahui keefektifan dari video digital pengalengan buah dan sayur melalui pretest dan posttest.

Subjek coba pada penelitian pengembangan ini adalah mahasiswa semester ganjil Jurusan Teknologi Industri Pangan di Akademi Komunitas Negeri Temanggung. Subjek coba berjumlah enam orang mahasiswa pada uji coba skala kecil dan dua puluh orang mahasiswa pada uji coba skala besar. Uji coba ini dilakukan dengan cara membandingkan keadaan sebelum dan sesudah menggunakan video digital (before - after) (Sugiyono, 2008, p. 415). Dalam hal ini terdapat satu kelompok eksperimen. Untuk lebih jelasnya dapat dilihat pada Gambar 2.

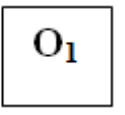

\section{$\mathrm{X}$}

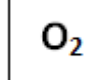

Gambar 2. Desain uji coba before-after

Jenis data yang diperoleh dari penelitian dan pengembangan ini ada dua jenis. Pertama, jenis data kualitatif yang diperoleh dari komentar, kesan serta tanggapan siswa, ahli materi dan ahli media. Kedua, jenis data kuantitatif yang diperoleh dari hasil pengisian lembar validasi ahli materi dan ahli media, respons siswa. Data tersebut dimaksudkan untuk mengetahui kualitas dari setiap komponen pengembangan video digital agar nantinya dapat diguna- kan dalam aktifitas pembelajaran. Data kuantitatif berupa skor tanggapan tentang kualitas produk baik ahli materi, ahli media, dan subjek coba dari siswa, serta data skor hasil pre-test dan post-test. Teknik pengumpulan data selama proses pengembangan produk menggunakan angket atau kuesioner dan tes. Instrumen kuesioner digunakan untuk mendapatkan data tentang kelayakan kualitas video digital yang dikembangkan berdasarkan aspek materi, aspek media, serta bagi mahasiswa. Instrumen kuesioner disusun menggunakan skala Likert. Penyusunan kuesioner dilakukan berdasarkan kisi - kisi, setelah disusun kuesioner divalidasi oleh expert judgement untuk menjamin instrumen yang digunakan valid. Soal tes merupakan instrumen yang digunakan untuk mengetahui tingkat pemahaman mahasiswa terhadap materi ajar setelah mereka belajar menggunakan media video digital pengalengan buah dan sayur. Soal test berupa pre-test dan post-test.

Teknik analisis data kelayakan produk video digital pengalengan buah dan sayur menggunakan skala Likert. Data hasil penelitian berupa tanggapan ahli media, ahli materi, dan mahasiswa tentang kualitas produk yang dikembangkan ditinjau dari aspek pembelajaran, aspek materi, dan aspek media. Data berupa komentar, saran revisi, dan hasil pengamatan selama proses uji coba dianalisis secara deskriptif kualitatif dan disimpulkan sebagai masukan untuk memperbaiki atau merevisi produk. Data berupa skor tanggapan ahli media, ahli materi, dan mahasiswa yang diperoleh dari kuesioner dianalisis secara deskriptif kuantitatif.

Dalam kuesioner diberikan lima pilihan untuk memberikan tanggapan tentang produk video digital yang dikembangkan, yaitu: sangat setuju dengan skor 5, setuju dengan skor 4, cukup dengan skor 3, tidak setuju dengan skor 2, dan sangat tidak setuju dengan skor 1 .

Skor yang diperoleh kemudian dikonversikan menjadi nilai, pada skala 5, dengan acuan tabel yang dikutip dari Sukardjo, (2005, p. 55), sebagaimana Tabel 1. 
Tabel 1. Kriteria Penilaian

\begin{tabular}{cccc}
\hline \multirow{2}{*}{ Skala } & \multirow{2}{*}{ Kriteria } & \multicolumn{2}{c}{ Skor } \\
\cline { 2 - 4 } & Sangat Baik & Perhitungan & Hasil \\
\hline 5 & Baik & $3+(0,6 \times 0,67)<\mathrm{X} \leq 3+(1,8 \times 0,67)$ & $\mathrm{X}>4,2$ \\
4 & Cukup & $3-(0,6 \times 0,67)<\mathrm{X} \leq 3+(0,6 \times 0,67)$ & $2,6<\mathrm{X} \leq 4,2$ \\
3 & Kurang & $3-(1,8 \times 0,67)<\mathrm{X} \leq 3-(0,6 \times 0,67)$ & $1,8<\mathrm{X} \leq 2,6$ \\
2 & Sangat Kurang & $\mathrm{X} \leq 3-(1,8 \times 0,67)$ & $\mathrm{X} \leq 1,8$ \\
1 & &
\end{tabular}

Data tes menggambarkan keefektifan video digital untuk pembelajaran dilihat dari sebelum dan sesudah menggunakan video digital pengalengan buah dan sayur, dihitung dengan menggunakan rumus $(N-$ gain) yang ditentukan berdasarkan rata-rata gain score yang dinormalisasi yaitu perbandingan dari skor gain. Peningkatan hasil belajar (gain score) adalah skor yang diperoleh mahasiswa dari pretest dan postest. Sedangkan skor gain maksimum adalah skor gain tertinggi yang diperoleh mahasiswa. Rata-rata gain yang dinormalisasi ( $\mathrm{N}$ gain) (Hake, 1998, p. 2) dinyatakan dengan persamaan sebagai berikut:

Keterangan:

$$
g=\frac{S \text { post }-S \text { pre }}{S \text { maks }- \text { S pre }}
$$

$S$ post : rata-rata skor postest

S pre : rata-rata skor pretest

$S$ maks : skor maksimal

Nilai yang sudah diperoleh kemudian diinterpretasikan dalam tabel klasifikasi gain score (Hake, 1998, p. 3), dengan kriteria sebagaimana disajikan pada Tabel 2.

Tabel 2. Klasifikasi Nilai Gain

\begin{tabular}{ll}
\hline \multicolumn{1}{c}{ Nilai } & Klasifikasi \\
\hline$(N$-gain $) \geq 0,7$ & Tinggi \\
$0,7<(N-$ gain $) \geq 0,3$ & Sedang \\
$(N$-gain $)<0,3$ & Rendah \\
\hline
\end{tabular}

\section{Hasil Penelitian}

Kegiatan pada tahap ini dilakukan melalui tiga tahapan yaitu analisis kebutuh- an, pengembangan produk, serta tahap validasi dan revisi. Tahap analisis kebutuhan dilakukan melalui dua tahap yaitu studi pustaka dan studi lapangan. Hasil dari studi pustaka bahwa mata kuliah teknologi pengolahan hasil pertanian bertujuan agar mahasiswa mampu menerapkan teknik pengolahan hasil pertanian dengan baik. Nilai yang diperoleh mahasiswa khususnya pada mata kuliah teknologi pengolahan hasil pertanian belum memuaskan. Hal ini dikarenakan terbatasnya sumber belajar di dalam kelas, yaitu hanya materi dari dosen pengampu mata kuliah. Sumber belajar lain berupa BKPM (buku kerja praktek mahasiswa) dan handout materi perkuliahan. Tingkat kehadiran mahasiswa saat perkuliahan teori lebih sedikit dibandingkan dengan perkuliahan praktikum. Sehingga tingkat kepahaman mahasiswa saat praktikum masih kurang.

Studi di lapangan dilakukan untuk mengetahui keadaan lembaga pendidikan, potensi yang dimiliki, proses pembelajaran. Akademi Komunitas Negeri Temanggung berlokasi di SMK Negeri 1 Temanggung. Sebagai salah satu Akademi Komunitas rintisan di Propinsi Jawa Tengah sehingga belum mampu menjadi pendidikan tinggi yang mandiri. Akademi Komunitas Negeri Temanggung merupakan salah satu Pendidikan Diluar Domisili (PDD) yang menginduk pada Politeknik Negeri Jember. Jurusan yang menjadi fokus pada penelitian ini adalah Teknologi Industri Pangan khususnya mata kuliah Teknologi Pengolahan Hasil Pertanian. Mata kuliah ini terdiri dari teori dan praktik. Proses belajar mengajar di 
Akademi Komunitas dilaksanakan setelah kegiatan belajar mengajar di SMK Negeri 1 Temanggung selesai. Hal ini menjadikan waktu belajar singkat, sedangkan materi yang disampaikan cukup banyak. Pada proses perkuliahan teori khususnya mata kuliah Teknologi Pengolahan Hasil Pertanian, dosen pengampu menggunakan handout, media untuk menyampaikan materi perkuliahan dengan powerpoint yang ditayangkan dengan LCD Proyektor. Perkuliahan praktikum dilaksanakan di laboratorium pengolahan SMK Negeri 1 Temanggung dengan peralatan yang cukup lengkap. Sarana pendukung lain adalah buku kerja praktik mahasiswa (BKPM).

Tahap pengembangan produk ini diawali dengan mengumpulkan bahan untuk memproduksi video digital. Dalam mengembangkan video digital ini juga disusun sebuah desain pembelajaran. Desain pembelajaran merupakan komponen yang penting dalam sebuah pembelajaran. Pembelajaran dapat berjalan dengan efektif dan efisien apabila disusun berdasarkan konsep pembelajaran dan sistem pembelajaran pada kurikulum yang dianut di Akademi Komunitas Negeri Temanggung. Pada penelitian pengembangan ini, desain pembelajaran disusun menggunakan model Dick, Carey, \& Carey (2001, pp. 2-3). Model desain pembelajaran yang digunakan dalam penelitian ini yaitu terdiri dari: (1) menetapkan tujuan instruksional umum; (2) menetapkan tujuan instruksional khusus, merumuskan indikator; (3) identifkasi karakteristik awal mahasiswa; (4) memilih materi kuliah; (5) menyusun strategi pembelajaran; dan (6) mengembangkan butir-butir tes.

Pada tahap pertama diperoleh informasi bahwa tujuan instruksional umum diambil dari Garis Besar Program Pengajaran (GBPP) mata kuliah Teknologi Pengolahan Hasil Pertanian (TPHP) yang digunakan di Akademi Komunitas Negeri Temanggung. Adapun tujuan instruksional umum yang digunakan adalah mahasiswa mengetahui tentang teknik pengolahan hasil pertanian, sedangkan tujuan instruksional khusus yang digunakan adalah mahasiswa dapat mengetahui dasar thermal dan produk pengolahannya; mahasiswa dapat menggunakan teknik pengolahan hasil pertanian dengan baik. Langkah selanjutnya adalah menetapkan indikator keberhasilan mahasiswa. Indikator yang ditentukan yaitu mahasiswa dapat mengenali produk-produk olahan dengan proses termal, mahasiswa dapat menyebutkan produk-produk olahan termal, mahasiswa dapat mendeskripsikan dasar proses pengolahan termal, mahasiswa dapat mempraktekkan proses thermal.

Mengidentifikasi tingkah laku awal dan karakteristik mahasiswa sangat perlu dilakukan untuk mengetahui kualitas perseorangan untuk dijadikan sebagai petunjuk dalam mempreskripsikan strategi dan pemilihan bahan ajar. Dalam pengajaran teknologi pengolahan hasil pertanian, mengidentifaksi tingkah laku dan karakteristik mahasiswa merupakan pondasi untuk merencanakan metode dan media pembelajaran. Mahasiswa mempunyai latar belakang pendidikan dan usia yang bervariasi, dan kebanyakan adalah orang dewasa. Orang dewasa mempunyai konsep diri untuk memecahkan masalah dan menghadapi resiko, orang dewasa mempunyai akumulasi pengalaman. Oleh karena itu pembelajaran dilakukan sebagai proses untuk bertukar pengalaman belajar.

Setelah melakukan semua tahapan di atas, langkah selanjutnya adalah menentukan materi yaitu pengalengan buah dan sayur sebagai aplikasi dari proses termal. Strategi pembelajaran yang diterapkan dengan kegiatan pembelajaran partisipatif sebagai upaya pembelajaran yang mengikutsertakan peserta didik dalam kegiatan pembelajaran. Instrumen penilaian berjumlah 20 soal pilihan ganda mencakup TIU, TIK dan indikator keberhasilan.

Tahap selanjutnya adalah pengembangan produk. Dimulai dengan mengumpulkan dan memproduksi bahan dan materi pengalengan buah dan sayur. Langkah selanjutnya membuat storyboard. Dilajutkan dengan proses produksi video digital pengalengan buah dan sayur. melakukan perekaman narasi dengan menggunakan 
digital recording dengan merk zoom $\mathrm{H}-1$. Tahap pengembangan produk dilanjutkan pengambilan gambar atau shooting. Shooting dilakukan di laboratorium pengolahan SMK Negeri 1 Temanggung, dengan menggunakan kamera video merk Sony SD1000. Setelah pengambilan gambar selesai, tahapan selanjutnya adalah proses editing gambar, video, suara dan teks. Editing dilakukan dengan menggunakan aplikasi Adobe Premier. Setelah tahap mixing selesai, langkah terakhir adalah rendering video untuk menjadi satu kesatuan video digital pengalengan buah dan sayur.

Video digital pengalengan buah dan sayur berisikan tentang turotial proses pengalengan buah dan sayur yang dilakukan di sebuah laboratorium pengolahan pangan. Mahasiswa diharapkan dapat memahami dengan baik isi video digital pengalengan buah dan sayur. Tampilan awal dari video digital berisi halaman pembuka yang memuat logo UNY, judul video dan identitas pembuat video. Adapun tampilan halaman pembuka adalah disajikan pada Gambar 3.

Halaman berikutnya menampilkan gambar ilustrasi tentang suasana industri pengalengan pangan, disertai dengan narasi pengantar isi video digital. Kemudian ditampilkan animasi gambar seluruh isi video digital disertai dengan backsound berganti dengan narasi tentang pengantar proses termal, dengan tampilan sebagaimana disajikan pada Gambar 4.

Video digital dilanjutkan dengan pengantar proses pengalengan, adab bekerja di laboratorium, persiapan alat, persiapan bahan dan proses pengalengan buah dan sayur secara berurutan yang ditampilkan oleh model. Salah satu tampilan dari proses pengalengan disajikan pada Gambar 5 .

Penjelasan materi pengalengan disertai dengan teks dan narasi untuk mempermudah mahasiswa memahami isi dari video digital pengalengan buah dan sayur. Pada bagian akhir akan ditampilkan teks berisi kesimpulan dari semua materi pengalengan buah dan sayur. Penutupan video digital berisi narasi ucapan terimakasih dan penayangan credit title disertai dengan backsound dengan tampilan yang disajikan pada Gambar 6.

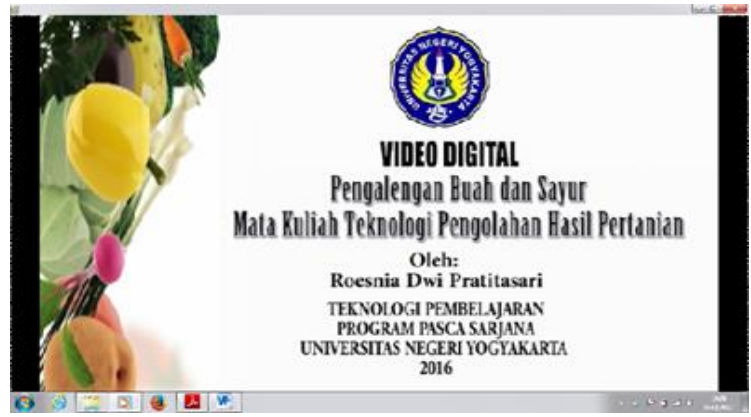

Gambar 3. Halaman pembuka

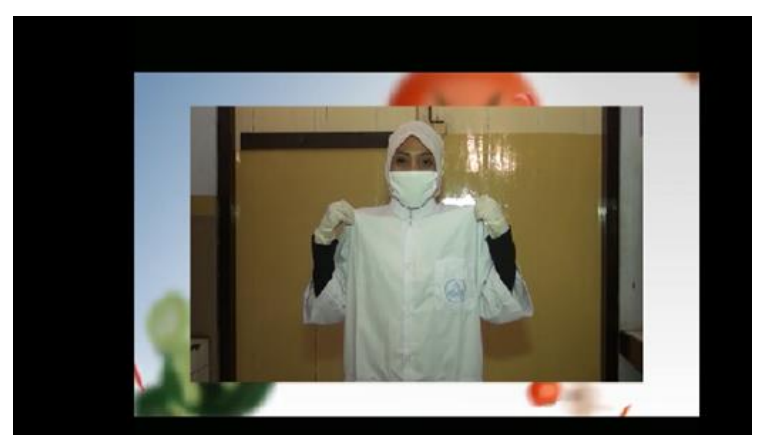

Gambar 4. Tampilan animasi rangkuman seluruh isi video digital

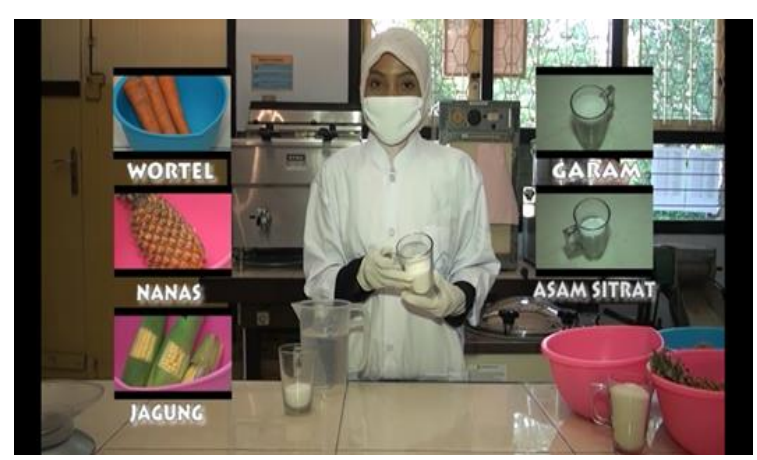

Gambar 5. Tampilan persiapan bahan yang diperagakan oleh model

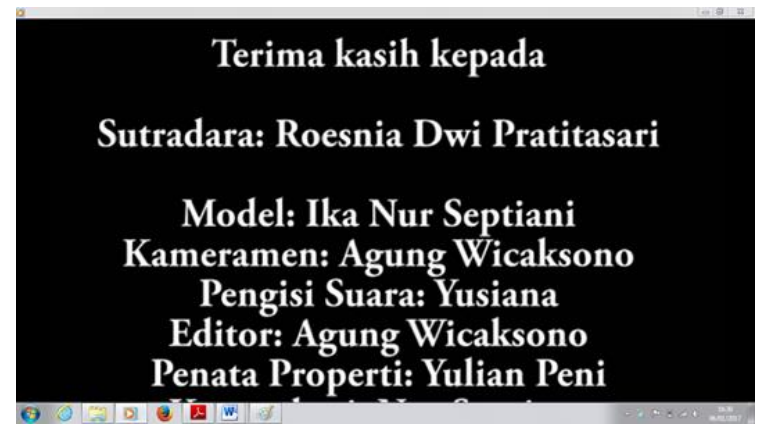

Gambar 6. Tampilan halaman penutup 
Tahap terakhir dari penelitian ini adalah validasi kemudian revisi yang bertujuan untuk menyempurnakan produk. Validasi dilakukan untuk mengetahui kelayakan video digital pengalengan buah dan sayur dilihat dari aspek media dan aspek materi. Validasi dilakukan oleh ahli media dan ahli materi. Ahli media yang ditunjuk adalah dua dosen dari program Pascasarjana UNY pada program studi Teknologi Pembelajaran. Ahli materi yang ditunjuk adalah dua dosen dari Fakultas Teknik Jurusan Pendidikan Teknik Boga.

\section{Hasil Validasi Ahli}

Hasil penilaian dari ahli media dijadikan tolak ukur kelayakan video digital dari aspek media. Dalam analisis data hasil validasi media pada aspek fungsi video digital terdapat 7 indikator mendapatkan rerata skor 4,15 dengan kategori baik. Pada aspek karakteristik video digital terdapat 7 indikator mendapatkan rerata skor 4,07 dengan kategori baik. Pada aspek kriteria pengembangan video terdapat 4 indikator mendapatkan rerata skor 4,23 dengan kategori sangat baik. Total keseluruhan dari aspek yang dinilai memperoleh kategori baik dengan jumlah 250 dan rerata sebesar 4,15. Hasil penilaian ahli media dapat dilihat pada Tabel 3 rangkuman hasil penilaian ahli media.
Untuk lebih mudah memahami rangkuman hasil penilaian ahli media dapat dilihat pada diagram Gambar 7.

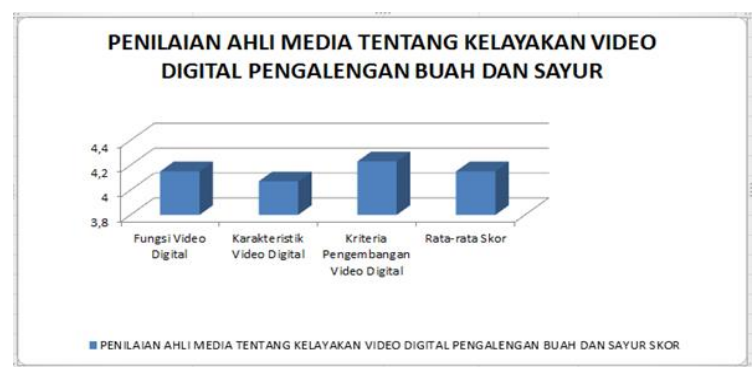

Gambar 7. Penilaian Ahli Media

Ahli materi bertujuan untuk menilai video digital dilihat dari aspek relevansi dengan GBPP, aspek kualitas materi dan aspek bahasa dan tipografi. Hasil penilaian ahli materi dijadikan tolak ukur kelayakan video digital dilihat dari aspek materi. Dalam analisis data hasil validasi materi pada aspek relevansi dengan GBPP terdapat 2 indikator yang dinilai mendapatkan rerata skor sebesar 4,4 dengan kategori sangat baik. Pada aspek kualitas materi terdapat 5 indikator yang dinilai mendapatkan rerata skor sebesar 4,06 dengan kategori baik. Pada aspek bahasa dan tipografi mendapatkan rerata skor sebesar 4,25 dengan kategori sangat baik. Total keseluruhan dari aspek yang dinilai memperoleh kategori sangat baik dengan jumlah 126 dan rerata sebesar 4,27 . Hasil penilaian ahli materi dapat dilihat pada Tabel 4 .

Tabel 3. Rekap Penilaian Ahli Media

\begin{tabular}{clccl}
\hline No. & \multicolumn{1}{c}{ Aspek Penilaian } & Jumlah & Rata-rata & \multicolumn{1}{c}{ Kategori } \\
\hline 1. & Fungsi Video Digital & 83 & 4,15 & Baik \\
2. & Karakteristik Video Digital & 57 & 4,07 & Baik \\
3. & Kriteria Pengembangan Video Digital & 110 & 4,23 & Sangat Baik \\
\cline { 3 - 5 } & Jumlah & 250 & 4,15 & Baik \\
\hline
\end{tabular}

Tabel 4. Rekap Penilaian Ahli Materi

\begin{tabular}{clccl}
\hline No. & \multicolumn{1}{c}{ Aspek Penilaian } & Jumlah & Rata-rata & \multicolumn{1}{c}{ Kategori } \\
\hline 1. & Relevansi dengan GBPP & 44 & 4,4 & Sangat Baik \\
2. & Kualitas materi & 65 & 4,06 & Baik \\
3. & Bahasa dan tipografi & 17 & 4,25 & Sangat Baik \\
& Jumlah & 126 & 4,27 & Sangat Baik \\
\hline
\end{tabular}


Tabel 5. Rangkuman Uji Coba Skala Kecil

\begin{tabular}{|c|c|c|c|c|}
\hline No. & Aspek Penilaian & Jumlah & Rata-rata & Kategori \\
\hline 1. & Materi & 134 & 4,42 & Sangat Baik \\
\hline \multirow[t]{2}{*}{2.} & Video Digital & 482 & 3,93 & Baik \\
\hline & Jumlah & 616 & 4,18 & Baik \\
\hline
\end{tabular}

Tabel 6. Perbandingan Hasil Pretest dan Posttest Mahasiswa

\begin{tabular}{llcccl}
\hline No. & \multicolumn{1}{c}{ Nilai } & Pretest & Postest & Gain Score & Kriteria \\
\hline 1. & Nilai Terendah & 2 & 6 & 0,50 & Sedang \\
2. & Nilai Tertinggi & 7,5 & 9,5 & 0,80 & Tinggi \\
3. & Total & 94,5 & 168,5 & 14,10 & \\
4. & Rata-rata & 4,73 & 8,43 & 0,71 & Tinggi \\
\hline
\end{tabular}

Untuk lebih mudah memahami rangkuman hasil penilaian ahli materi dapat dilihat pada diagram Gambar 8.

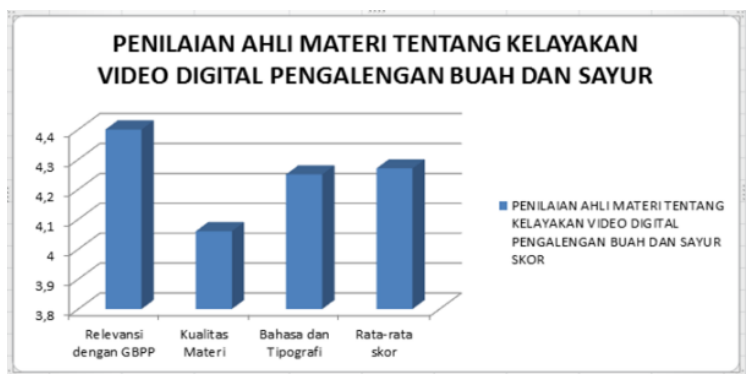

Gambar 8. Penilaian Ahli Media

\section{Hasil Uji Coba Produk}

Uji coba skala kecil dilakukan terhadap 6 mahasiswa jurusan Teknologi Industri Pangan di Akademi Komunitas Negeri Temanggung. Aspek yang dinilai pada uji coba skala kecil ini adalah aspek materi dan aspek video digital. Hasil penilaian menunjukkan rerata skor pada aspek media sebesar 4,42 dengan kategori sangat baik, sedangkan rerata skor pada aspek video digital sebesar 3,93 dengan kategori baik. Total keseluruhan dari aspek yang dinilai memperoleh kategori baik dengan jumlah 616 dan rerata sebesar 4,18 Hasil rangkuman penilaian pada uji coba skala kecil dapat dilihat pada Tabel 5 .

Untuk lebih mudah memahami hasil dari uji coba skala kecil dapat dilihat pada diagram Gambar 9.

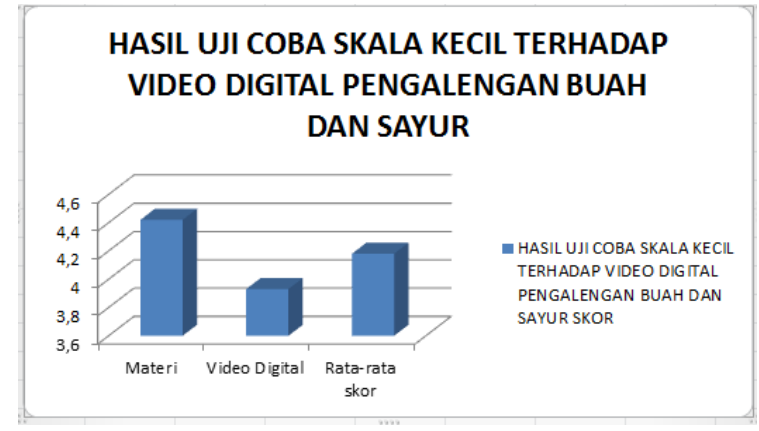

Gambar 9. Hasil Uji Coba Skala Kecil

Uji coba skala besar dilakukan pada mahasiswa Teknologi Industri Pangan berjumlah 20 orang, tidak termasuk mahasiswa yang telah melakukan uji coba skala kecil. Uji coba skala besar bertujuan untuk mengetahui keefektifan video digital pengalengan buah dan sayur pada pembelajaran teknologi pengolahan hasil pertanian dan kenaikan hasil belajar mahasiswa sebelum dan sesudah menggunakan video digital. Analisis data hasil belajar dihitung dengan menggunakan teknik standart gain (gain standar) yaitu kenaikan skor diperoleh dari skor akhir (posttest) dikurangi dengan skor awal (pretest) kemudian dibagi dengan pengurangan antara skor maksimum dengan skor awal (pretest). Kriteria efektifitas produk ditentukan berdasarkan hasil pretest dan posttest mahasiswa dilihat dari jumlah rata - rata kenaikan skor (gain score) yang disajikan pada Tabel 6 . 
Hasil pretest dan posttest yang diperoleh mahasiswa berdasarkan tabel diatas diketahui nilai terendah dan nilai tertinggi pada pretest adalah 2 dan 7,5 dengan jumlah rata-rata 4,73 . Nilai terendah dan nilai tertinggi pada posttest atau setelah menggunakan video digital adalah 6 dan 9,5 dengan jumlah rata-rata 8,43. Peningkatan hasil belajar mahasiswa (gain score) mahasiswa setelah menggunakan video digital berjumlah 14,10 dengan rata-rata 0,71 dikategorikan tinggi. Dapat disimpulkan bahwa produk video digital pengalengan buah dan sayur efektif digunakan dalam pembelajaran khususnya pada mata kuliah teknologi pengolahan hasil pertanian.

Hasil penelitian ini senada dengan beberapa penelitian yang dilakukan oleh Riana \& Gafur (2015, pp. 212-224) bahwa multimedia interaktif yang dikembangkan untuk pembelajaran bahasa inggris layak dan efektif digunakan sebagai salah satu alat bantu di dalam pembelajaran. Penelitian lain yang dilakukan oleh Zinnurain \& Gafur (2015, pp. 157-168) bahwa multimedia pembelajaran interatif yang berisikan tata cara solat ini layak dan efektif digunakan dalam pembelajaran. Respon siswa terhadap multimedia ini termasuk kategori sangat tinggi. Penelitian lain yang dilakukan oleh Purwanti \& Haryanto (2015, pp. 190-200) bahwa motion graphic yang dikembangkan untuk mata pelajaran pendidikan kewarganegaraan ini layak dijadikan sumber belajar. Media ini efektif digunakan di dalam pembelajaran serta dapat melatih siswa untuk berpikir kritis.

Sebagai hasil produk pengembangan, video digital pengalengan buah dan sayur ini dikemas dalam kepingan DVD. Video digital ini mempunyai kelebihan dan kekurangan. Adapun kelebihan dari video digital ini adalah mampu menyajikan keseluruhan proses pengalengan buah dan sayur, dengan memadukan gambar, animasi, dan audio dengan jelas, sehingga materi dapat dipahami dengan mudah. Video digital ini dapat digunakan sebagai sumber belajar mandiri oleh mahasiswa. Di samping kelebihan, video digital ini mempu- nyai kekurangan. Kekurangan dari video digital ini adalah penyampaian informasi dilakukan secara satu arah atau tidak interaktif.

\section{Simpulan}

Berdasarkan hasil penelitian dan analisis data yang telah diuraikan, maka diperoleh kesimpulan dalam penelitian pengembangan ini sebagai berikut. Pertama produk yang dihasilkan dalam penelitian dan pengembangan ini terbukti layak digunakan dalam proses perkuliahan ditinjau dari aspek materi, aspek media. Hal ini dibuktikan dari hasil penilaian validasi ahli materi, penilaian validasi ahli media.

Kedua, respons mahasiswa terhadap produk yang dikembangkan menunjukkan kesan atau tanggapan yang baik yang dibuktikan dengan hasil kuesioner dalam penelitian. Ketiga, video digital pengalengan buah dan sayur hasil pengembangan ini terbukti efektif digunakan sebagai sumber belajar. Hal ini terbukti dari kenaikan hasil belajar siswa pada uji keefektifan video digital ini yaitu rerata sebesar 4,73 pada saat pretest, sedangkan hasil belajar siswa pada saat posttest diperoleh rerata sebesar 8,43 . Berdasarkan hasil tersebut diperoleh kenaikan skor rerata sebesar 0,71 poin yang termasuk dalam kategori "tinggi".

Berdasarkan hasil penelitian dan pengembangan dapat disarankan hal-hal sebagai berikut. Pertama, bagi mahasiswa diharapkan dalam proses pembelajaran dapat memanfaatkan video digital pengalengan buah dan sayur dengan baik agar dapat lebih meningkatkan penguasaan materi pengalengan buah dan sayur. Dapat mengikuti semua proses pengelangan ketika perkuliahan praktek dengan baik dan benar.

Kedua, bagi dosen diharapkan bisa mengembangkan media pembelajaran lainnya sebagai sumber belajar di Akademi Komunitas Negeri Temanggung. Dosen dapat menyajikan materi yang lain dalam pengembangan media belajar yang dapat mengatasi permasalahan belajar di Akademi Komunitas Negeri Temanggung. 


\section{Daftar Pustaka}

Anderson, R. H. (1987). Pemilihan dan pengembangan media untuk pembelajaran. Jakarta: Rajawali Pers.

Arsyad, A. (2011). Media pengajaran. Jakarta: PT Raja Grafindo Persada.

Borg, W. R., \& Gall, M. D. (1983). Educational research: An introduction (4th ed.). New York: Longman Publishing.

Daryanto. (2012). Model pembelajaran inovatif. Yogyakarta: Gava Media.

Dick, W., Carey, L., \& Carey, J. O. (2001). The systematic design of instruction (5th ed.). New York: Longman.

Hake, R. R. (1998). Interactive-engagement versus traditional methods: A sixthousand-student survey of mechanics test data for introductory physics courses. American Journal of Physics, 66(1), 64-74. https://doi.org/10.1119/1.18809

Kneller, G. F. (1967). Foundation of education. New York: John Wiley and Sons Inc.

Presiden Republik Indonesia. Peraturan Pemerintah RI Pasal 1 ayat 12 Tahun 2014 tentang Akademi Komunitas (2014).

Purwanti, A., \& Haryanto, H. (2015). Pengembangan motion graphic pembelajaran mata pelajaran pendidikan kewarganegaraan kelas I sekolah dasar. Jurnal Inovasi Teknologi Pendidikan, 2(2). Retrieved from https://journal.uny.ac.id/index.php/ jitp/article/view/7609

Riana, E., \& Gafur, A. (2015). Pengembangan multimedia interaktif pembelajaran bahasa inggris materi teks deskriptif untuk siswa SMP/MTs. Jurnal Inovasi Teknologi
Pendidikan, 2(2). Retrieved from https://journal.uny.ac.id/index.php/ jitp/article/view/7611

Riyana, C. (2007). Pedoman pengembangan media video. Jakarta: P3AI UPI.

Sadiman, A. S. (2008). Media pendidikan. Jakarta: PT. Raja Grafindo Persada.

Salim, P., \& Salim, Y. (1996). Kamus Bahasa Indonesia kontemporer. Jakarta: Modern English Press.

Smaldino, S. E., Lowther, D. L., \& Russel, J. D. (2011). Instructional technology and media for learning (10th ed.). PBoston, MA: Allyn \& Bacon.

Sudjana, D. (2007). Ilmu dan aplikasi pendidikan. Bandung: PT. Imperial Bakti Utama.

Sugiyono. (2008). Metode penelitian kunatitatif kualitatif dan $R \mathcal{E} D$. Bandung: Alfabeta.

Sukardjo. (2005). Evaluasi pembelajaran. Diktat mata kuliah program studi teknologi pembelajaran Universitas Negeri Yogyakarta. Yogyakarta: tidak diterbitkan.

Ulumudin, I. (2015). Efektifitas pendirian akademi komunitas dalam mendukung masterplan percepatan dan perluasan pembangunan ekonomi Indonesia. Jurnal Pendidikan Dan Kebudayaan, 21(1).

Zinnurain, Z., \& Gafur, A. (2015). Pengembangan multimedia pembelajaran interaktif pendidikan agama islam materi tata cara sholat untuk sekolah dasar. Jurnal Inovasi Teknologi Pendidikan, 2(2). Retrieved from https://journal.uny.ac.id/index.php/ jitp/article/view/7605 